\title{
Regulation Implementation Effectiveness of Outdoors Users in Town Square of Bandung, Indonesia
}

\author{
Harum Bunga Melati ${ }^{*}$ \\ Department of Social Studies Education, Faculty of Social Sciences Education, \\ Universitas Pendidikan Indonesia, Bandung, 40154, West Java, Indonesia.
}

Received: 2020-04-28; Accepted: 2020-09-22; Published: 2020-10-27

\begin{abstract}
Bandung Square in Indonesia is a public outdoors that has many visitors from various regions. One of the parts that make up Bandung town square is sign boards as a symbol of written rules that all square visitors must obey. The background of this research is that Bandung town square is equipped with a lot of sign boards with different rules in every corner. Besides, civil service police units and public protection officers also take part in guarding around Bandung town square, so the researcher want to know more about the implementation of the rules contained in the Bandung town square because the researcher still found several violations. This study aims to determine the regulation implementation effectiveness of outdoors users in town square of Bandung. The advantages of this goal are as a reflection for social institutions in maintaining public regulation and as a reminder to town square visitors to be more obedient to the rules that applied to maintain comfort. This type of research is a qualitative research conducted using descriptive methods. Research data were collected using interviews with instruments in the form of questions about the subject matter. The data collected was described using qualitative-descriptive analysis. Based on data findings in the field, it shows that the implementation of the regulation in Bandung town square is quite effective, because there are still some violations found and their social institutions are still less firm and conducive in carrying out social control there. So, public order still has not been achieved according to the expected goals.
\end{abstract}

Keywords: Discipline; Effectiveness; Regulation Implementation

How to Cite: Melati, H. B. (2020). Regulation Implementation Effectiveness of Outdoors Users in Town Square of Bandung, Indonesia. Journal of Contemporary Governance and Public Policy, 1(2), 108-120.

Permalink/DOI: https://doi.org/10.46507/jcgpp.v1i2.7 


\section{Introduction}

Bandung town square is a public outdoors located in the center of Bandung. Called a public outdoors because of square is a place where people from anywhere can gather. Bandung town square was renovated during the reign of Ridwan Kamil. This square has a unique characteristic which the grass in the middle of the square is a synthetic.

Outdoors is a place where some activities are held. Many activities can be done in an outdoors such as: a place to play especially for children, a place to exercise, a place for social interaction, and a place for seeking fresh air.

Bandung town square has several facilities such as a beautiful garden cubic that can be used by visitors for taking selfies. In addition, there is a children's playground and under the square is a basement which contains a place for people to sell food, toys, trinkets and others as well as other facilities such as toilets and parking lots. The diverse of the facilities draws attentions not only native residents of Bandung but also from outside of Bandung.

The regulations contain rules that must be obeyed by every person and if it is violated the doer will get a penalty both in the form of punishment or warning. The stronger the threat and the force of sanctions, the more effective it will be. Furthermore, the more obedient the citizens to the law orders, the more orderly course of life will be.

The effectiveness of the punishments will significantly guarantee the realization of law in society. Besides applied regulation for outdoors users, there is also a social institution that directly working on site to give a warning to users who violate the legitimate rules.

Social institution is a collection of social norms created to carry out community functions to achieve a goal that is considered important by the community and the square has an institution such as Satpol PP who is in charge of controlling visitors.

The management of Bandung town square is so neat and clean as is the Bandung mosque, but it cannot be denied that there are still violations that appear to the community although there are clear rules. In addition to the written rules, there are also Satpol PP and Linmas who are always there to maintain order and security.

According to scholar from
Indonesia, violations means contradictory which their actions are contrary to applicable regulations (Al-Fijawi, Aung, \& Muhammad, 2019). The most common violation is that visitors still use sandals when sitting on synthetic grass although this is not allowed. Even though there are no written rules there, but the Satpol PP and Linmas always warn and inform that there are rules for removing sandals when they want to sit on synthetic grass.

The rule for removing sandals is for other visitors to feel comfortable when they want to sit on the grass. Management result of Bandung Grand Mosque is also very neat and clean. There are public facilities such as toilets, slippers, and others. This mosque also has rules that should be obeyed by the community. However, there are still violations found such as the prohibition of sleeping in the mosque and there are still people who sleep in the mosque. It will disrupt the comfort and safety of people who want to worship there. As it is known that Bandung Grand Mosque is always filled with activities such as recitation, dawn prayers in congregation, and others. Even though Satpol PP and Linmas only guarded outside the mosque and did 
not go inside, the regulations were written as it is.

The need for an effective implementation of regulation in order to create public order in which effectiveness is a key element to achieve the goals or targets that have been determined in every organization, activity or program. Called as effective if achieved goals or objectives as determined. Based on observations and interviews conducted by researchers that the rules there are fairly effective but there are still violations that occur due to lack of law awareness and lack of firm social institutions in dealing with violations that occur.

This study tries to see the regulation implementation effectiveness of outdoors users in Bandung town square. Many studies have examined Bandung town square, but no one has discussed it in terms of the rules of the square. The research taken is about the elements forming the square, the development of the square from time to time, as well as visitors' perceptions of Bandung square facilities. Research by Ramadhan, Nurzuraida, Wibowo, \& Wijaya (2018) was conducted by students of the architecture study program called (Ramadhan, Nurzuraida, Wibowo, \& Wijaya, 2018) in 2018 discussing Bandung square which experienced changes over time, by examining the elements forming the square which includes field, park, pedestrian path, parking lot, board rules of conduct, and other facilities. Similar to this paper, the research of used a descriptive qualitative method and found a topic of discussion on sign board but only explained the condition and location of the sign board. In contrast to this article, the focus tends to the implementation of the rules of public outdoors. So this paper will complement Gema's research.
In 2015, research by Putra, Azwir, Octaviany, \& Nilamsuci (2015) was published by Reka Karsa Journal. The study, entitled "Kajian Transformasi Bentuk dan Fungsi Alunalun Bandung Sebagai Ruang Terbuka Publik", discusses the change in layout and function of Bandung square from the beginning to the seventh stage. The focus of research is on changes in the design of the square as well as administrative functions and socio-cultural functions. In this study there was no specific discussion regarding the regulation sign board so that this paper will complement ( Putra, Azwir, Octaviany, \& Nilamsuci, 2015).

Mua \& Suheri (2017) wrote an article which appeared in the scientific magazine UNIKOM (Vol. 15, No. 2) with the title "Tingkat Kepuasan Masyarakat Tentang Alunalun Kota Bandung Sebagai Ruang Terbuka Publik". Discusses the level of visitor satisfaction with the quality of services and facilities in Bandung town square. In this study, the popular one is in the level of community satisfaction with the comfort, safety and care of community officials. However, details of security, security and care are carried out by officers. It differs from this article, which presents the role of Satpol PP officers in ensuring the safety and comfort of Bandung town square visitors. Supported by this paper, it can complement (Mua \& Suheri, 2017).

\section{Research Methods}

In this research, the writer uses descriptive research method because it is related to current events and related to the present. Firstly the data obtained is compiled, then explained and analyzed. The author conducts research with a descriptive study because it is suitable with the characteristic of the problem and the 
purpose of the research to be obtained is not to test a hypothesis, but try to get a real picture about the regulation implementation effectiveness of outdoors users in the square of the city of Bandung. The reason the writer uses descriptive studies is because in the research the author wants to find out whether the implementation of the regulation for outdoors users in Bandung town square is effective. The author here is not testing the hypothesis but rather looking for conclusions from some of the information data obtained.

The qualitative approach was chosen by the researcher because the problem chosen by the researcher was still considered to be temporary and developed or changed in accordance with the results obtained in the field, in this case the Bandung town square. A qualitative approach in analyzing the problem under study requires a descriptive disclosure. Through a qualitative approach in this study, it is expected to obtain a deeper illustration and understanding of the rules used by outdoors.

The location of this research is a place to conduct research with the aim of obtaining data from research subjects. The research site is spotted in Bandung town square, where the square has rules that must be obeyed by outdoors users, located on Jl. Asia Afrika, Balonggede, Regol, Bandung, West Java 40251.

In this study, the object of research is Bandung town square and the subjects in this study is the visitors of Bandung town square and Satpol PP. Visitors and Satpol PP were chosen as research subjects because they knew, mastered, and understood the purpose of the study and then visitors were chosen because visitors who felt the rules and Satpol PP were institutions that controlled the visitors.
The research will explore information through an individual approach in accordance with the research objectives. Qualitative research is expected to be able to get to know the subject of research in depth in order to get information. Determining the subject in a study is intended so that researchers can obtain as much information about the purpose of research.

\section{Results and Discussion}

\section{Violations committed by outdoors users in Bandung town square}

From the results of the study found that in general the violations committed by outdoors users in Bandung town square are still quite high. This is evidenced from the results of the answers expressed by respondents when conducting interviews and the observations of researchers.

Some violations committed by outdoors users were littering, trading in prohibited places, and wearing footwear on synthetic grass. From the results of an interview conducted to one of Satpol PP, there are still street vendors selling at the prohibited place even though it has been warned by Satpol PP. Based on observations seen in the field that there are a group of families who casually use footwear on synthetic grass when Satpol PP had not work yet.

Based on the theory, deviant behavior are all actions that deviate from the norms prevailing in the social system and give rise to the efforts of those in charge of the system to correct deviant behavior (Widjaya, 1984).

So it can be said that someone committing an offense is included in the category of deviant behavior because there was already an order that applied there, but still commits an offense. Types of violations visitors to the square are included in 
the primary deviation where the primary deviation is a deviation committed by someone but the offender is still acceptable to the community. This deviation is temporary, is not repeated and can still be tolerated by the community.

A person breaks a rule because of the loose rules and the lack of strictness of a social institution in giving warns or sanctions that have been set. These violations are generally carried out both by individuals and groups such as street vendors. Violations that occur around the square such as the number of vehicles that parked is not orderly and corresponding to the rules.

Similar to the violations that occurred in the Bandung town square, the Bandung Grand Mosque which is located nearby also has written rules and regulations such as not being allowed to sleep in the mosque or sell around the mosque. However, violations found in the field are still many visitors who sleep in the mosque and many sellers who sell their goods around the mosque. Based on the results of interviews, violations that have occurred is that there were still visitors who wear sandals into the mosque, this is very unnatural where the mosque is a place of worship and should be kept clean. There were already many facilities available such as a place to put sandals and should be used as well as possible so that they are dutiful to the rules.

\section{Controls Performed by Satpol PP in Creating Public Order for Outdoors Users in Bandung Town Square}

The civil service police unit or known as Satpol $P P$ is a regional government apparatus tasked with maintaining peace, public order, and enforcing regional regulations. The organization and work procedures of Satpol $P P$ are stipulated in the
Regional Regulation. Satpol PP can be domiciled in the Province and Region / City. Pamong Praja comes from the words Pamong and Praja, Pamong means caregiver who comes from the word Among which also has its own meaning which is caring while Praja is a civil servant. Based on the above terms it can be concluded that Satpol $P P$ is the one who oversees and secures government decisions in the working area.

From the results of the study, it was found that in general the control carried out by Satpol PP in creating public order for outdoors users in Bandung town square is still quite low. This is proven from the results of the answers expressed by respondents when interviewed and observed by the researcher. Public order is a condition that involves the implementation of human life as a shared life. In the narrow sense, violators of public order are only limited to violations that fall within the provisions of the legislation, whereas in the broad sense, violators of public order are not only those who violate the provisions of the legislation but all legal values and principles that live and grow in public awareness including the values of propriety and the principles of general justice.

The large number of violations that still felt made social institutions like Satpol PP control over the violations. In the meaning of control, social control is a mechanism to prevent social deviations and invites and directs people to act and behave according to applicable norms and values. With the existence of good social control is expected to be able to straighten out community members who behave in deviant or disobedient behavior.

Based on interviews conducted with one of Satpol PP that in the working mechanism of Satpol 
$P P$, not every day they work; but work a day off and there is a separate part (shift) but in practice in the field done flexibly.

Existing regulations are certainly made for the sake of order and mutual comfort but sometimes there are still many visitors and sellers who commit violations, and here Satpol PP has a role to provide direct control. Social control has two ways: (1) Preventive: social control that is carried out before a violation occurs. It means that it is concerned with prevention to prevent violations; (2) Repressive: social control is carried out after people commit an act of deviation. At first Satpol PP had carried out preventive types of control such as by using symbols or verbally used to warn violators so that they did not commit violations again but if they were told they were still in violation then repressive type of social control would be taken by bringing him/her to the authorities for a counseling.

Violations that are often handled by Satpol PP are violations committed by street vendors, where they peddle their merchandise not in available places. Satpol PP always give warning but from my observations in the field; Satpol PP is less firm so that street vendors dare to refute the warning, and based on interview results that when there are street vendors who are peddling their merchandise in a prohibited place even though there is a Satpol PP who was on guard but was not warning at all. Though the notion of warning is aimed to the offender. Can be in oral or written form. The purpose of warning is to make the offender immediately realize his mistake.

Doing social control over this in order to create public order. In line with the understanding of public order that public order is a condition that involves the implementation of human life as a shared life. When controlling effectively, it will create public order and mutual comfort. Satpol $P P$ must be active in controlling so that violators will not repeat their mistakes.

\section{The Role of Social Control in Creating Public Order for Outdoors Users in Bandung Town Square}

From the results of the study it was found that in general, the role of social control in creating public order for outdoors users in Bandung town square can be fairly assertive. This is evidenced from the results of the answers expressed by respondents when conducting interviews.

In creating public order for outdoors users in the Bandung town square, it requires a firmness in the rules of order as a social control tool, which issuitable with social control theory that focuses on techniques and strategies that regulate human behavior and bring it to the adjustment or obedience to the rules of society. Someone follows the law in response to certain controlling forces in one's life. Someone becomes a criminal when the controlling forces are weak or lost. Based on this understanding, the role of social control is very important in managing visitors in order to create public order. Legal norms are one of the norms in which there are sanctions if violations occur in the implementation of these norms. Law is an official regulation or custom made by the authorities to regulate the association of life in society (Hossain \& Rahi, 2018). Understanding of the law according to (Ali, 2010) is considered as rules or ways of behaving that are obligatory with the imposition of a sanction and imposed by a control authority, regarding the violation. Legislation is one of the legal norms in force in Indonesia. 
Social control can be a form of sanctions, like the definition of sanctions which states that social sanctions are a form of social control. Many people consider social supervision as a limitation of the actions of the authorities, leaders or superiors of other parties that are controlled or led not to deviate from the applicable provisions or regulations.

According to the statement above, it can be concluded that sanctions are the right way to limit a person's behavior in acting, it does not mean that every action carried out is limited by law but is limited in order to create a social order.

In Bandung town square, many sanctions are written such as: (a) trading in prohibited places is subject to a fine of Rp. 1000,000; (b) urinating, defecating carelessly subject to a forced fee of Rp. 250,000; (c) smoking in public places is subject to forced costs of Rp. 5,000,000; (d) buying from street vendors in the red zone is subject to a forced fee of $\mathrm{Rp}$. 1000,000; (e) littering carries a fine of Rp. 250,000; (f) trading in the most restricted areas is subject to a fine of Rp. 1,000,000; (g) allowing pets to roam in public places is subject to a forced fee of Rp. 5,000,000; (h) damaging public facilities is subject to forced costs Rp. 5,000,000.

Some sanctions are applied to this visitor so that the atmosphere becomes safe and orderly. The lack of visitors' awareness to the law, but when there are sanctions that have been mentioned above, visitors tend to obey the law more because in essence the Indonesian people obey the law when there are sanctions or rules that are so strict. This sanction was imposed on the visitor who committed the violation based on the results of an interview with one of Satpol PP that he said the sanction was applied when the visitor violated it continuously even though he had previously been warned. Warning is a social sanction which can be given to someone who makes a mistake (other than administrative sanctions such as criminal / civil law). These social sanctions are not written and are often implicit or not explicitly stated. Social sanctions are given by the community against someone who commits a deviation of the values and norms that are existed in the community itself. Where, social sanctions are usually in the form of actions aimed at making the recipient deterrent sanction to commit deviations again. Usually social sanctions will end when the guilty person has admitted his mistake and apologized for the mistake, then over time the social sanctions will stop by themselves. The sanctions are applied so that the violators deter and do not commit the violations again.

\section{Regulation Implementation for Outdoors Users in Bandung Town Square}

In the book Pengantar Ilmu Pendidikan, rule is a series of regulations that must be obeyed in a situation or in a life order. Rule according to Hasan Langgulun is the arrangement and rules in relation to one part with another part (Kusuma, 1973).

From the results of the study found that in general the regulation implementation for outdoors users in Bandung town square can be fairly good. It is proven from the results of the answers expressed by respondents when conducting interviews and the observations of researchers.

Bandung town square has various regulations such as rule and not only that, there are social institutions such as the Satpol PP who are tasked with maintaining security and public order. This is same with 
statement according to Amir Daiem Indrakusuma that rule is a series of regulations that must be regulated obey in a situation or in a life order.

The rules were made to discipline visitors to the square, but in its implementation there were still many people who committed violations such as the answer from one of the respondents during the interview, said that they still saw various violations such as littering, wearing sandals on elastic grass and there were still street vendors who not selling in the area.

The regulation implementation in the square is still not conducive because it is match with observations made by researchers, seeing that there are still violations that occur both in the square itself and in Bandung Grand Mosque itself. The rules have been made in written form but visitors have not yet known them so there are still many who commit violations such as there are still many visitors who sleep in the mosque, sell around the mosque, do not neatly fold the prayer but the condition of the mosque is fairly clean and many woman's prayer gown (mukena) provided there, however in the arrangement is still less conducive so that the susceptible mukena will fall down.

Satpol PP are ready to monitor visitors, because visitors do not only come from Bandung. There are still many visitors who come from outside who do not understand the rules or regulations there. A survey of researchers in the field saw a group of families wearing sandals on synthetic grass, if seen from the dialect, it was clear that they were not Bandung resident and did not know the rules so they were vulnerable to violations because also the regulations regarding removing footwear were no written rules made so this also triggers frequent violations.

The square is always crowded with visitors even more late afternoon, the atmosphere of the square is increasingly crowded, even when holiday the atmosphere of the square is increasingly crowded. This crowd made this regulation implementation tend to decrease, because based on observations by researchers in the field that the Satpol $P P$ left the obvious garbage in front of it, whether because of ignorance or because Satpol PP itself was lazy to pick up or warn those who did it. This did not make the rules realized because there is no support from various parties to be aware of the importance of obeying the rules.

\section{Role of Satpol PP in Creating Public Order for Outdoors Users in Bandung Town Square}

From the results of the study, it was found that in general the role of the Satpol PP in creating public order for outdoors users in Bandung town square is still quite good and very important. This is proven from the results of the answers expressed by respondents when interviewed and the observed by researchers.

Satpol $P P$ is a Regional Government apparatus in maintaining peace and public order and enforcing regulations. Based on the explanation above, the role of Satpol PP is very important for the establishment of a public order.

For the sake of order and mutual comfort, the city government uses Satpol $P P$ as an institution tasked with regulating order and comfort for visitors to the square. The role of Satpol PP is very important considering there are rules of order which are not written so that Satpol $P P$ informs the rules to visitors who do not understand and know about the regulation there. 
When the researchers conducted a field study, they saw several Satpol PP sweeping the streets where there was a lot of rubbish and cleaning the rubbish between the cubic plants, and at that time Satpol PP was picking up litter scattered around the square. In addition, there were visitors who reported the loss of motorcycle keys and the observation of Satpol PP researchers helped to announce this through the secretariat office located next to the mosque. The group of children who were doing the study tour lost one of their colleagues, and then the school reported it to Satpol $P P$. Besides, there was a mother who was confused looking for a toilet and asked for instructions from Satpol PP and then the municipal police gave way to the mother. Every afternoon Satpol PP gives an announcement to always maintain the cleanliness of the square, maintain order and security, forbid traders to peddle merchandise in prohibited places, and tell the traders not to force visitors to buy goods; because it can disturb the comfort of visitors. Please visitors provide goods, food, drinks and toys at the place that has been available and Satpol PP will be ready to direct visitors when there are items to be purchased.

When researchers make observations during the day and morning it is rare to find such an announcement and begin to take the decision that it is only done in the afternoon and indeed through observation in the afternoon that the square is so crowded by visitors. In the morning, when the researchers conducted the study, there was no Satpol PP on guard and based on the results of interviews with Satpol PP that they only started operating at around eight or nine in the morning. When there was no Satpol PP, there was a group of families who casually walked with sandals on synthetic grass. This is evidence that the role of Satpol PP is important in maintaining public order and comfort.

During the day, some of Satpol $P P$ were found operating in the middle of synthetic grass. The researcher did an interview with the Satpol PP who was on duty alongside the area and was still at the training stage saying that they were operating in dealing with street vendors who peddled merchandise not in accordance with the available places, most of them were often warned but still doing things that's because it can not wait if you just wait for visitors to come. Based on observations there were traders who protested to Satpol $P P$ who did not accept to get a warning.

At that time, Satpol PP officers used crackle as a place of sandals and tidied up the messy sandals everywhere and then told the visitors to keep their sandals on because there was a case of visitors losing sandals and shoes. Satpol PP has handled various cases such as visitors who lost shoes, sandals, or wallets, and when the culprit was found, they were immediately taken to the authorities.

The role of Satpol PP is very important for the creation of public order, because a written code of conduct is not enough if no one directly goes to the field to deal with violations that occur. Seeing the Bandung great mosque which has rules as well as a place of worship, but there are still many visitors who use it for a place of trade even though it is clearly prohibited but there are still selling around the mosque. Then there are still visitors who sleep in the mosque even though written rules are written not to sleep in the mosque. The absence of Satpol PP can make the atmosphere ineffective, but Satpol PP must also be firm in 
responding to violators of these rules. The role of the community is also necessary here because it is also impossible in the mosque that there is Satpol PP who is on guard so we have the awareness to warn visitors who are still sleeping in the mosque.

\section{Rules Affects Public Order for Outdoors Users in Bandung Town Square}

From the results of the study found that in general the order is very influencing public order for outdoors users in Bandung town square. This is proven from the results of the answers expressed by respondents when interviewed and the observed by the researcher.

Order according to etymology is a system or arrangement of rules that must be obeyed or obeyed. So the rules are made to limit the behavior of individuals in terms so that individuals comply with the rules that have been made and ultimately achieved a social order. Social order is a set of social structure relationships, social institutions and social practices that maintain, look after, and carry out normal ways of dealing and behaving. This state of social order is achieved if the relationship between order, related institutions, and other parties is balanced as intended above that the existence of an order is made to achieve social order, that is public order, so an institution such as a social institution that goes directly to the field is needed to see condition and realize the rules and the orders that have been made to overcome unwanted things.

Order is very influential in public order, but it will be apparent if the order is only just order without support from other parties on the importance of the order. Rules are made based on the legal norms that exist in the region and adapted to the conditions and situations that are needed and desirable to be achieved regarding these objectives.

According to (A. W. Widjaya, 1984) legal awareness is a condition where there are no conflicts of life in society. Society in a balanced, harmonious and harmonious life. Legal awareness is accepted as awareness, not accepted as a force. Although there are restrictions from outside the human self or society itself in the form of legislation.

Legal awareness can be interpreted as an individual or community perception of the law (Salman, 1993). This perception may or may not be the same as applicable law. The law here refers to applicable law and aspired law. Thus, the law includes written law and unwritten law. Legal awareness is related to values that grow and develop in a society. Thus the community obeys the law not because of a force but because the law is in accordance with the values that exist in the community's own circumstances.

Some indicators of legal awareness: (1) Legal knowledge is one's knowledge of certain behaviors regulated by law. Such knowledge is closely related to behavior that is prohibited or behavior that is permitted by law. In addition, knowledge is closely related to the assumption that the community is considered to know the contents of a regulation when the regulation has been enacted;

(2) Understanding the law is interpreted as a number of information a person has about the contents of the rules of a particular law. In other words, understanding the law is simply an understanding of the content and purpose of a rule in a particular law and its benefits for those parties whose lives are governed by the regulation (Salman, 
1993). In terms of understanding the law, it is not required that a person must first know of a written rule controlling a matter. However, what is seen here is how their perceptions in dealing with various things that have to do with the norms prevailing in society. This understanding is usually manifested through their attitudes towards daily behavior;

(3) Legal attitude is defined as a tendency to accept the law because of respect for the law as something beneficial or profitable if the law is obeyed. A legal attitude will involve people's choice of law that matches the values that exist in themselves so that eventually the community accepts the law based on respect for it;

(4) The pattern of legal behavior is the main thing in legal awareness, because here it can be seen whether all regulations applied or not in the community. Thus the extent of legal awareness in society can be seen from the pattern of legal behavior (Salman, 1993).

The rules contained in Bandung town square have various forms in the form of written rules such as prohibiting littering, trading in prohibited places, buying at street vendors who sell in restricted places, urinating / defecating in inappropriate place, smoking in places public, allow pets to roam in public places, damage public facilities, are prohibited from stepping on, sitting, damaging, uprooting, in plant areas and there are unwritten rules such as prohibiting wearing footwear on synthetic grass. Likewise the rules made in Bandung great mosque such as dressing modestly and covering genitals, avoid mixing different types, prohibited from selling around the mosque, do not sleep in the mosque, footwear are removed, are prohibited from sitting at the entrance. Finally, there is a regulation such as no smoking on the tower of Bandung Grand Mosque.

The rules made have their own sanctions and Satpol PP is ready to carry out social control in order to create public order. The social controls used in the form of warning and social control used as sanctions. Warning can be verbal or written and sanctions used by Satpol PP when a warning has been given but does not change anything. Public order can be achieved if the implementation of the order goes well and Satpol PP is firm in warning and most importantly when visitors are aware of the applicable law.

\section{Regulation Implementation Can Be Called Effective for Outdoors Users in Bandung Town Square}

From the results of the study found that in general the regulation implementation can be called to be effective if it generates public order from outdoors users in Bandung town square. This is proven from the results of the answers expressed by respondents when interviewed and the observed by the researcher.

Order is a rule that must be obeyed by the community. Bandung Square has rules made for visitors of the square. A rule is said to be effective if the purpose of the rule is fulfilled and achieved. In addition to the rules, in the square there is a social institution such as Satpol PP which is tasked for maintaining public order. The effectiveness of implementing the rules depends on how visitors accept and adhere to the regulation. Lack of legal awareness of the rules makes the effectiveness of the rules to be reduced.

Legal compliance follows certain developments and one's mentality, it is necessary to identify the factors that influence legal compliance, which in this case (Soekanto, 1990) divides it into three 
stages and the Indonesian state is included in the preconventional stage where humans obey the law because focus attention on the consequences if the law is violated. The process that occurs at this stage can actually be divided into two more stages namely the stage of physical strength (a person obeys the law so that he avoids negative punishment or sanctions) and the hedonistic stage (a person obeys the law or breaks the law for his own satisfaction).

Based on the above statement, the legal awareness of the Indonesian people is still said to only depend on the rules that applied. If the rules that applied have such strict sanctions then they will comply with these rules.

Based on the results of interviews conducted by researcher, respondents also answered that someone committed an offense when the rules and sanctions were clearly stated due to lack of legal awareness from himself.

The rules of order in Bandung square are good, accompanied by the presence of social institutions in charge and the management of the facilities is good, but sometimes lacks cleanliness. Legal awareness is closely related to legal compliance or legal observance that is concrete in human attitudes, acts, or behaviors. When there is no rule of law but the visitor does not engage in deviant behavior or violations, it can be said he has legal awareness.

Based on observations made by the researcher in the field that there is still a lack of legal awareness from visitors to the square as there are still many who use footwear on the synthetic grass so that the implementation of the order is less effective. When a person commits an offense and is reprimanded then he still commits the same offense, it can be said that there is something wrong in the individual, so we cannot do anything arbitrarily to the rules of order and blame the implementation of the order, what should be seen is the amount violations that continue to decrease, if from time to time the number of violations is always reduced there can be said that the implementation of the order is effective.

Social order is a condition where social relations run orderly according to the values and social norms prevailing in society. In other words, social order is a condition in which social relationships that take place between members of the community take place in consent, unity, and harmony in accordance with the interactions, norms, and social values that applied. The result of social unity is social welfare.

Welfare as a social order can be seen in Law of the Republic of Indonesia number 6 of 1974 concerning Basic Provisions for Social Welfare, article 1 paragraph 1 , as follows:

"Social welfare is a system of life and social, material, and spiritual life, which is encompassed by a sense of safety, morality and inner peace, which makes it possible for every citizen to make an effort to meet physical, spiritual, and social needs as well as -both for self, family, and society by upholding human rights and human obligations in accordance with Pancasila. "

Based on these definitions, it can be seen that social welfare is a social order. Community order is said to be conducive if the community feels that there is a guarantee of safety and peace. 


\section{Conclusion}

Violations committed by outdoors users in Bandung city square are still in numbers like street vendors (PKL) who sell, visitors are found to bring food to synthetic grass, use shoes when crossing synthetic grass, and do not park vehicles neatly. These violations are generally carried out both by individuals and groups. Someone violates because of the loosening of an orderly rules, the lack of strictness of a social institution in giving a warning and there is no awareness of visitors to obey the rules.

Rules have been made in written form but there are still many visitors who do not obey even do not know these rules so that some violations are still found. Another example is the violation found in Bandung Square Mosque area, such as many visitors who sleep in the mosque, sell around the mosque, do not neatly fold the mukena, but the condition of the mosque is fairly clean and the mukena provided there are many, only that the organizers still less conducive. The role of Satpol PP is very important for the creation of public order, because a written rules is not enough if no one directly goes to the field to deal with violations that occur.

Rules must be made as clear as possible, especially rules in written form because not everyone understands if this type of rule uses verbal rules.

Satpol PP has a very important role but in its implementation it must still be corrected and be firm against violations that occur and do not be afraid to warn actions that are not in accordance with the rules of discipline.

The community must have an awareness of the law in order to create mutual order.

\section{Acknowledgements}

I would thank Universitas Pendidikan Indonesia and all those contributed to finalization of this article.

\section{References}

Al-Fijawi, M. F. A., Aung, M. A. S. @ U. T., \& Muhammad, M. K. (2019). Violations of Basic Rights of Prisoners In Conventional and Islamic Law: Theory and Practice. Intellectual Discourse, $27(2)$.

Ali, A. (2010). Menguak Teori Hukum (Legal Theory) dan Teori Peradilan (Judicial Prudence) Termasuk Interpretasi UndangUndang (Legisprudence). Jakarta: Kencana.

Hossain, M. B., \& Rahi, S. T. (2018). Murder: A Critical Analysis of the Common Law Definition. Beijing Law Review, 09(03), 460-480.

https://doi.org/10.4236/blr.2 018.93028

Kusuma, A. D. I. (1973). Pengantar Ilmu Pendidikan (Usaha Nasional, Ed.). Malang.

Mua, G. P., \& Suheri, T. (2017). Tingkat Kepuasan Masyarakat Tentang Alun-Alun Kota Bandung Sebagai Ruang Terbuka Publik. Majalah Ilmiah UNIKOM, 15(2). https://doi.org/10.34010/miu .v15i2.566

Putra, A. D., Azwir, M., Octaviany, V., \& Nilamsuci, R. (2015). Kajian Transformasi Bentuk dan Fungsi Alun-Alun Bandung Sebagai Ruang Terbuka Publik. Jurnal Reka Karsa, 3(3). https://doi.org/https://doi.or g/10.26760/rekakarsa.v3i3.69 6

Ramadhan, G., Nurzuraida, G., Wibowo, H., \& Wijaya, K. (2018). Elemen Pembentuk Ruang Terbuka Publik Alun- 
Alun Kota Bandung. Ensains Journal, 1(1), 56-62. https://doi.org/10.31848/ens ains.v1i1.57

Salman, S. (1993). Beberapa Aspek Sosiologi Hukum. Bandung: Alumni.
Soekanto, S. (1990). Sosiologi Suatu Pengantar, Edisi IV. Jakarta: Penerbit Rajawali.

Widjaya, A. W. (1984). Kesadaran Hukum Manusia dan Manusia Pancasila. Jakarta: Era Swasta.

(C) 2020 by Author. Submitted for possible open access publication under the terms and conditions of the Creative Commons Attribution (CC-BY-SA) license (https://creativecommons.org/licenses/by-sa/3.0/). 